\title{
CSR as a Potential Motivator to Shape Employees' View towards Nature for a Sustainable Workplace Environment
}

\author{
Linghui Kong ${ }^{1}$, Muhammad Safdar Sial ${ }^{2}$, Naveed Ahmad ${ }^{3}{ }^{10}$, Mariana Sehleanu ${ }^{4}$, Zhihui Li ${ }^{5, *}$, \\ Malik Zia-Ud-Din ${ }^{6}$ and Daniel Badulescu ${ }^{4}$ (i) \\ 1 School of Accounting, Guangdong University of Finance \& Economics, Guangzhou 510320, China; \\ 20131818@gdufe.edu.cn \\ 2 Department of Management Sciences, COMSATS University Islamabad (CUI), Islamabad 44000, Pakistan; \\ safdarsial@comsats.edu.pk \\ 3 Faculty of Management Studies, University of Central Punjab, Lahore 54000, Pakistan; \\ naveeddgk2010@gmail.com \\ 4 Department of Economics and Business, Faculty of Economic Sciences, University of Oradea, 410087 Oradea, \\ Romania; mavancea@uoradea.ro (M.S.); dbadulescu@uoradea.ro (D.B.) \\ 5 Department of Vocal Music, Wuhan Conservatory of Music, Wuhan 430000, China \\ 6 Department of Law, Islamia University, Bahawalpur 63100, Pakistan; malik.ziauddin@iub.edu.pk \\ * Correspondence: lihui8631321@sohu.com
}

check for updates

Citation: Kong, L.; Sial, M.S.;

Ahmad, N.; Sehleanu, M.; Li, Z.;

Zia-Ud-Din, M.; Badulescu, D. CSR as a Potential Motivator to Shape Employees' View towards Nature for a Sustainable Workplace Environment. Sustainability 2021, 13, 1499. https://doi.org/10.3390/ su13031499

Received: 8 January 2021

Accepted: 25 January 2021

Published: 1 February 2021

Publisher's Note: MDPI stays neutral with regard to jurisdictional claims in published maps and institutional affiliations.

Copyright: (c) 2021 by the authors. Licensee MDPI, Basel, Switzerland. This article is an open access article distributed under the terms and conditions of the Creative Commons Attribution (CC BY) license (https:// creativecommons.org/licenses/by/ $4.0 /)$.

\begin{abstract}
Prior studies in the contemporary literature have largely ignored the important role of corporate social responsibility (CSR) in shaping employees' views of self and nature. Although researchers have recently started to pay considerable attention to explore the link between CSR and environmental sustainability, determining how CSR can be effective in shaping the proenvironmental behavior of employees that is missing in the existing literature. The objective of the present research study is to test the impact of microlevel CSR activities to induce environmental performance of an organization with a mediating effect of employees' pro-environmental behaviors. This study argues that CSR activities of an organization motivate the workers to rethink the relationship between self and nature; hence, they are encouraged to participate in activities that are helpful in terms of preserving the environment, such as participating in pro-environmental activities at the workplace. The proposed model of the study was tested in the banking sector of Pakistan and analyzed by using the structural equation modeling (SEM) technique in AMOS software. The results revealed that microlevel CSR activities, using employee proenvironmental behaviors as a mediator, directly and indirectly influence environmental performance of a bank. The results of the present study are helpful for policymakers of different banking institutions to understand how they can reduce the environmental footprint of their bank by using a well-planned CSR program that can induce transcendent emotions in employees to create a sustainable environment.
\end{abstract}

Keywords: microlevel CSR; view of self and nature; transcendent emotions; proenvironmental behavior; environmental performance

\section{Introduction}

Businesses around the globe are becoming more socially responsible due to pressures from different stakeholders, such as consumers, competitors and governments [1]. The concept of corporate social responsibility (CSR) has been around for decades, but its boundaries are still evolving even in 2021 [2]. The prior literature has largely addressed the impact of CSR activities on the financial output of an organization [3,4]. This is quite a recent in the literature, that contemporary researchers have begun to explore the relationship between CSR activities and environment management [5]. Hence, recent researchers have shown greater concern and want to address the widespread issue of environmental dilapidation through CSR initiatives [6]. Industries around the globe are key players adding fuel to 
the risk of environmental degradation. Traditionally, it was thought that the prime concern of enterprises is to make profit, but in recent years, this traditional model has been replaced with a business philosophy of earning the profits not at the expense of society [7]. Stakeholders in the current digital age are more knowledgeable due to the advancement in digital technology; hence, they are interested in learning about the socially responsible behavior of businesses in order to be assured that businesses are contributing positively to preserve the environment [8]. In response to such emerging changes, developed countries such as the USA and countries from the European Union (EU) have already raised their environmental standards, due to which businesses in developed countries have significantly changed their behaviors toward the environment [9]. However, the real problem lies in the developing countries of the world, where environmental standards are far behind as compared to developed nations. To further aggravate the situation, most of the developing economies are emitting a significant amount of pollution, which is a serious threat for planet Earth [10].

Pakistan, being a developing nation, is experiencing the serious challenge of changing climatic conditions, due to which the country is facing several problems, including heavy floods, droughts, extreme temperatures and a poor air quality index [11]. The country needs to take serious measures at every level to efficiently deal with the current environmental issues. This is the time for the country to rethink its environmental management and take initiatives to preserve the environment at all levels, including the individual (employee) level and group (organizational) level. CSR, in this context, may be a good strategy to reduce the environmental footprint of enterprises. Studies have shown that well-planned CSR initiatives can improve the environmental performance of an organization $[12,13]$. However, what has been missing in the prior literature is the potential role of CSR at the individual level (employees) in reducing the environmental footprint of enterprises. We define microlevel CSR (micro-CSR) in line with the definition of Rupp and Mallory [14], who contended that micro-CSR is concerned with the CSR experience at the individual level. We further argue that there is a growing concern among contemporary scholars to realize the importance of individual psychological feelings toward CSR activities undertaken by a specific organization to shape their orientation towards nature $[15,16]$. Although Rupp and Mallory [14] mentioned extending micro-CSR to any individual level inside or outside of an organization, we focused on a narrower aspect by considering an employee's intervention toward environmental improvement at workplace. Unfortunately, in Pakistan, individuals' thinking toward the relationship of self and nature is poor due to the lack of knowledge and understanding of the fact that every individual is important in the efforts to preserve the nature. Further, individuals are less concerned about the widespread issue of climate change in the country because of their poor knowledge and passive behavior toward the environment. The findings of the present study may be the dawn of a new horizon in which individuals at workplaces are expected to rethink their relationship with nature, and therefore a better sustainable future of the country can be hoped for.

We further argue that employees spend a significant amount of time at their workplaces, and so they may be key players in reducing the environmental footprint of an organization if they, at the individual level, show responsible behaviors to preserve the environment-for example, not consuming unnecessary electricity, not wasting organizational resources, etcetera. Further, out of the 200 million population of Pakistan, the labor force constitutes more than 72 million [17], which is a huge number, thus neglecting its role in promoting environmental sustainability is unwise. Hence, the objective of the present study is to examine the relationship between micro-CSR activities and environmental performance, with the mediating role of employees' proenvironmental behavior.

The proposed model of the present study was tested in the banking sector of Pakistan. This sector was chosen because in Pakistan, the current state of CSR initiatives from the business community is poor and the banking sector is one the leading sectors of the country, which contributes significantly to CSR activities [18]. Further, the banking sector is not 
considered to be a pollution-emitting sector, and perhaps this is the reason that banks in Pakistan invest significantly in CSR activities, but the majority of such activities include community services such as supporting different community-building activities, including investing in education and donations in the name of charity [19]. Unlikedeveloped nations, investing CSR funds in promoting environmental sustainability is not the priority of many developing nations [20]. The findings of the present study will bring it to the focus of policymakers that environmental sustainability may be achieved only when all sectors of the community (manufacturing, service and others) assume their responsibility to preserve the environment.

The study at hands adds to the existing literature in many ways; for example, the prior studies in the existing literature underexplored the relationship of CSR initiatives at the individual level, which is of utmost importance for environmental sustainability. Moreover, this is a pioneering study in the context of a developing country, which aims to highlight the importance of employees at the individual level to preserve the environment. Lastly, the present study is important in addition to recent literature as it brings to the surface this mistaken belief of those in the service sector that this sector is not a pollutionemitting sector, and hence they might not be worried about their contribution towards environmental sustainability. The findings of this study will be helpful to change this behavior of the service sector towards the environment.

\section{Literature and Hypotheses}

The reason for businesses to participate in CSR activities is to achieve sustainability by improving competitiveness and the environment [21]. According to Carroll [22], CSR is the economic, legal, social and philanthropic engagement of a business in which organizations maximize their wealth by responding to the community and environment positively. Likewise, in his book "Social Responsibilities of the Businessman," Bowen and Johnson [23] indicated that business has an impact on society, so the goal of businesses should be in line with social goals and values. Environmental performance can be improved when adopting a CSR plan leads to such interventions like, lower emissions, waste management systems and low energy consumption, playing an important role in eliminating the negative impact of business processes on the environment [24]. Currently, researchers and policymakers are more concerned with CSR as consumers are looking for environmentally friendly goods and services. During the last decade, CSR has been recognized as one of the most important competitive business strategies [2]. Furthermore, there are numerous studies on CSR, but there is no clear definition of it, as there is no universal consensus on CSR activities. To be successful, firms must live up to public expectations. Internally targeted organizations have a longer lifespan, and businesses that care more for their consumers are more likely to succeed in the modern competitive world. The CSR is the company's commitment to adhere to these plans, make decisions and adhere to standards of conduct that are of value to the general public [25]. Several scholars have identified the impact of CSR on a firm's performance, noting that it improves with CSR activities [3,26]. Shabbir and Wisdom [27] reported that CSR has significant meanings in a successful organizational life. Scholars have recently considered the relationship between CSR and environmental performance and found that CSR substantially improves environmental performance $[24,28]$. For certain companies, CSR is an approach to increase social power. "The notion of Green environment" is receiving a lot of attention from all stakeholders throughout the world, and consumers are pulled to support those organizations which are socially responsible. Organizations can utilize their CSR programs to expand their social capital and pull in consumers who back green activities [4]. In the same vein, for organizations, handling the environment well is critical and this is reflected in their CSR programs. It is not exclusively a socially dependable practice; it is also an acceptable business norm according to various stakeholders [29].

CSR initiatives of an organization are key touchpoints to shape the behavior of employees towards nature, because when workers see that their organization is concerned 
with environment management and is making real efforts to reduce environmental hazards, they feel positively for their organization [12]. In line with the theory of norm reciprocity, it is expected that employees will reciprocate positively with their organization due to its engagement in CSR activities [30]. Hence, we expect that microlevel CSR activities are intended to induce the environmental performance of an organization, so in light of the above literature and discussion, the following hypothesis is proposed:

Hypothesis 1. Microlevel CSR activities are associated with organizational environmental performance.

Organizations have begun to understand the relationship between environmental protection and sustainability and its effectiveness [31]. Although the topic of CSR has been around for decades, in recent times, there has been a lot of pressure on businesses from stakeholders to act socially [29]. As a result, CSR policies and procedures are and will be influential at the organizational level (macro-CSR) and at the individual level (micro-CSR). It is notable that the theoretical discussion supports the positive impact of CSR on employee behavior, especially to shape their environment-related behavior [32,33]. For example, CSR activities involve social responsibility [34], and as a result, can lead to employees being engaged in positive behaviors towards the environment and community. In addition, CSR practices can provide a high level of care for employees and their needs [35]. Therefore, based on the theory of social exchange [36] and the norm of reciprocity [37], in which people feel compelled to benefit from other people, we expect employees to reciprocate to the organizations, by building confidence in this positive behavior with their organizations. Goyal et al. [38] noted that values related to the need of sustainability affect the perception and behavior of employees in the welfare system; that is, employees know and share such values, which motivate them to demonstrate proenvironmental behavior. Similarly, there is a general argument that an organization that supports the environment and sustainable activities can permeate an organization's climate [39]. Because employees' attitudes toward CSR policies and practices define an organization's "standards of accountability, responsibility, and ethics" [40], we argue that CSR creates value for employees and consequently contributes to their task-related proenvironmental behavior. In addition, Farid et al. [33] stated that employees' perceptions of environmental management activities influence their negotiation for environmental behavior, which in turn attempts to enhance the environmental performance of an organization. Likewise, there have been different researchers in the contemporary literature who acknowledge that the environmental footprint of an organization can be significantly reduced through the responsible behavior of employees; for instance, the studies of Tolppanen and Kang [41] and Koiwanit and Filimonau [42] are some of the recent examples in the contemporary literature. We, in this regard, argue that employees spend a lot of time at their workplaces, and if their orientation towards environmental management is improved, then a significant improvement in the overall environmental performance of an organization is expected. CSR at the microlevel is an agent of change that develops positive emotions on the part of employees to promote sustainability, because when an organization communicates its CSR initiative with its employees, they feel elevated and want to respond to the organization in positive way. Hence, they are encouraged to rethink their relationship with nature with a larger perspective by recognizing their importance as an individual to a better and sustainable environment. Along these lines, we propose:

Hypothesis 2. Employees' proenvironmental behavior positively influences organizational environmental performance.

Hypothesis 3. Employees' proenvironmental behavior mediates the relationship between microlevel CSR and environmental performance.

Based on above literature and discussion the following proposed research model has been framed (see Figure 1). 


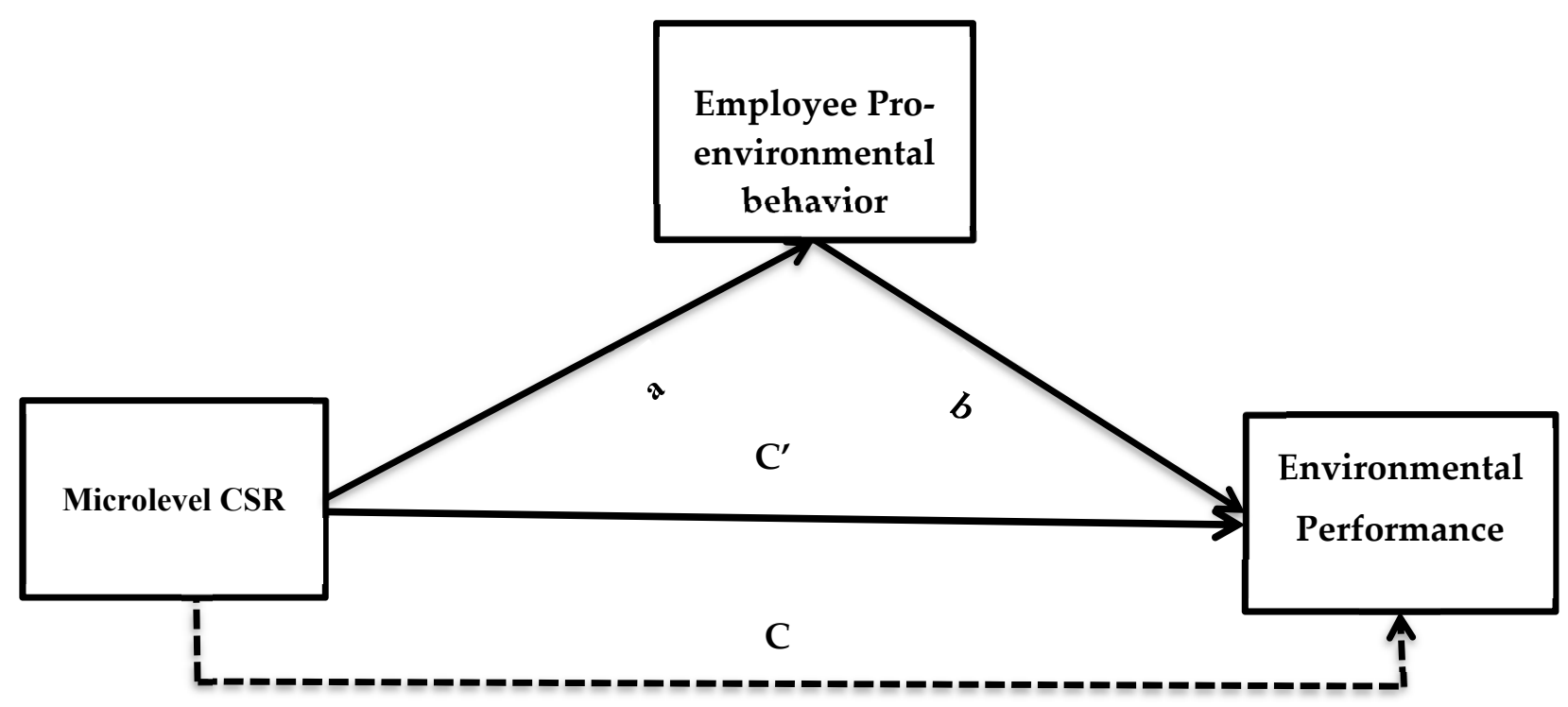

Figure 1. Proposed research model: This figure is drawn based on the authors' conception; the relationships between the variables are drawn based on relevant literature. There are three variables in the above research model, among which microlevel CSR is the independent variable, environmental performance is the dependent variable and employees' proenvironmental behavior is the mediating variable. $\mathrm{C}^{\prime}=$ indirect direct effect of $\mathrm{X}$ on $\mathrm{Y}$ with the effect of the mediator; $\mathrm{C}=$ direct effect of $\mathrm{X}$ on $\mathrm{Y}$ without the mediator; $\mathrm{a}=$ direct effect from microlevel CSR on employee environmental behavior; $\mathrm{b}=$ direct effect from employees' proenvironmental behavior on environmental performance.

\section{Methodology}

\subsection{Sample, Data Collection and Measurements}

The data for the present study were collected from the banking sector of Pakistan. To represent the banking sector, we selected two cities of Pakistan named Lahore and Karachi. The selection of these two cities was logical to serve the purpose of the present study, as first, these are the largest cities of Pakistan where multiple branches of all banking institutions are established; second, these two cities are among the most polluted cities in Pakistan. It is notable that Lahore is ranked as the most polluted city in the world [43]. The banking sector of Pakistan was purposefully chosen for the present study due to two specific reasons: First, CSR is still in its infancy in Pakistan because of different factors, including a lack of CSR knowledge, passive behavior of government and a lack of commitment from top management [44]; however, the banking sector is one of those few sectors in Pakistan in which CSR activities are obvious, and banking institutions actively invest in CSR initiatives. Second, most of the banking sector of Pakistan invests in CSR activities with a philanthropic mindset, such as supporting communities in education, charity and the like, but the importance of CSR to address the environment is not the priority of the banking sector of Pakistan. Hence, to change this mindset of the banking sector towards the environment through CSR is something to be achieved by the findings of present study.

Before the actual phase of data collection, we purposefully searched the banking institutions that were actively involved in CSR initiatives. This resulted in the selection of six banks, namely Habib Bank Limited (HBL), National Bank of Pakistan (NBP), United Bank Limited (UBL), Allied Bank Limited (ABL), Meezan Bank Limited (MBL) and MCB Bank. This selection was made on three grounds: (1) these are the largest banks of Pakistan, having their presence almost in every city of the country; (2) these banks were actively involved in CSR affairs and have a separate webpage for sustainability reporting; (3) these six banks cover the majority of banking consumers of Pakistan [45].

After this initial assessment, we contacted the spokespersons of the selected banks in these two cities, and those who agreed to facilitate us in the data collection activity, were then approached by the researchers. The widespread second wave of COVID-19 posed a serious challenge for researchers in collecting data from the banking personnel, 
as most of the banking institutions did not allow us to physically meet their staff. To handle this situation, we managed a detailed session with the spokespersons of selected branches to collect the data on behalf of the researchers. Hence, the questionnaires were handed over to each spokesperson to be filled by different respondents. We, in this connection, distributed 1000 questionnaires in both cities (500 for each). After several repeated visits by the researchers, we finally received a total of 389 fully completed questionnaires that were useful for data analysis; in this way, the response rate of the present study was almost 39\%.

The survey items of the present study were adapted from already existing scales, so the validity and reliability of the instrument was pre-established. For instance, the items of micro-CSR were adapted from the study of Turker [46], who used a six-item scale for measuring CSR at the microlevel. Likewise, the three items to measure employee proenvironmental behavior were taken from the study of Bissing-Olson et al. [47]. Lastly, the items of environmental performance were taken from the study of Blok et al. [48]; there were five items to measure this variable. We arranged a five-point Likert scale for all the above mentioned scales.

\subsection{Handling of Social Desirability and Common Method Bias}

In order to address social desirability, we took different steps; for instance, the survey items in the questionnaire were randomly scattered in order to break any intended sequence developed on the part of the respondents. Further, we requested the spokespersons to clarify the respondents that their shared information would be kept confidential and would not be shared with anyone. The data of the present study were collected from the same individual, and hence the issue of common method bias may be a potential threat for the present research. To avoid this issue, we took two steps: First of all, through the spokepersonos, we tried to make it clear to the respondents that their honest opinion is very important for the findings of the present study, so that they would willingly provide their genuine responses. Likewise, we performed a single-factor analysis in order to see if there was a single dominant factor, as recommended by Harman [49]. The results of single-factor analysis revealed that there was no such dominant factor, because the highest variance shared by one factor was $33.4 \%$, which is less than $50 \%$; hence, the common method bias is not a potential issue in our data. Table 1 below represents the demographics of the sample who participated in the survey.

Table 1. Demographic profile of the sample.

\begin{tabular}{ccc}
\hline Gender & Frequency & \% \\
\hline Male & 231 & 59.4 \\
Female & 158 & 40.6 \\
Age (years) & & \\
$21-25$ & 67 & 17.2 \\
$26-30$ & 82 & 21.1 \\
$31-40$ & 164 & 42.2 \\
$>40$ & 76 & 19.5 \\
Experience in years & & \\
$1-3$ & 62 & 15.9 \\
$4-6$ & 149 & 38.3 \\
$7-10$ & 93 & 23.9 \\
$>10$ & 85 & 21.9 \\
\hline
\end{tabular}

\section{Results}

In the data analysis phase, first of all, we tested the factor loadings of all items in SPSS software through factor analysis in order to determine if there was some issue of factor loading for survey items; for example, cross-loading of an item onto more than one factor or weak loadings. For this purpose, we rotated all items through the varimax rotation from principal component factor analysis in SPSS. The initial extraction of items showed good factor loadings for all items, and all items were well loaded onto their respective factors, 
which mean there was no issue of factor loading. Next, we also checked the reliability values of our all three variables through assessing Cronbach alpha values $(\alpha)$. The results revealed that all variables met the criteria of reliability analysis, as all values were above the threshold level of 0.7 (Table 2).

Table 2. Factor loadings and reliability results.

\begin{tabular}{ccccc}
\hline Variable & Items & $\begin{array}{c}\text { Loading } \mathbf{b} \\
\text { (Min-Max) }\end{array}$ & $\begin{array}{c}\boldsymbol{t} \text {-Value } \\
\text { (Min-Max) }\end{array}$ & $\boldsymbol{\alpha}^{\mathbf{c}}$ \\
\hline CSR & 6 & $0.69-0.86$ & $11.92-16.38$ & 0.79 \\
PRB & 3 & $0.74-0.82$ & $13.51-19.82$ & 0.71 \\
EPF & 5 & $0.71-0.93$ & $13.77-17.94$ & 0.82 \\
\hline
\end{tabular}

Notes: ${ }^{b}$ factor loading; $\alpha^{c}$, Cronbach's alpha coefficient; CSR, corporate social responsibility; PRB, proenvironmental behavior; EPF, environmental performance.

The above two tests confirmed that the data was quite appropriate for analysis at further levels, so we conducted confirmatory factor analysis (CFA) using AMOS software in order to determine if the data fit our theoretical model. The results of CFA are presented in Table 3 , in which we have reported model fit indices, correlation results, average variance extracted (AVE), composite reliability (CR) and discriminant validity results. According to the results of Table 3 , the model fit values for both the absolute fit indices ( $\chi^{2}$, RMSEA, GFI) and comparative fit indices (IFI, CFI) produced adequate results to establish that our theoretical model fits to the data well. Further, we also tested correlation values in comparison to the square root of AVE values for all variables to establish the discriminant validity of our instrument; the rule of thumb is that if the square root value of the AVE for a variable is larger than the correlation values, then it is established that the items of one variable discriminate from the items of other variables. In this connection (see Table 3), the value of correlation amongst CSR and proenvironmental behavior (PRB) was $0.218^{* *}$ and CSR and environmental performance (EPF) was $0.236^{* *}$, whereas the value of the square root of the AVE for CSR is 0.768 , which is larger than the correlational values, thus establishing that the criteria of discriminant validity is fulfilled. Further, the values of the correlations among different variables are within moderate ranges (the highest was $0.236^{* *}$ ), which raise our confidence to establish that the issue of multicollinearity is not a potential threat in the dataset of the present study. Moreover, the standard deviation (SD) results confirmed that there was less variability in our data, because all the values of SD were less than 1.

Table 3. Discriminant validity, correlations and average variance extracted (AVEs).

\begin{tabular}{|c|c|c|c|c|c|}
\hline Variables & Mean & SD & CSR & PRB & EPF \\
\hline CSR & 3.48 & 0.731 & 0.768 & & \\
\hline PRB & 4.11 & 0.492 & $0.218^{* *}$ & 0.748 & \\
\hline \multirow{3}{*}{ EPF } & 3.91 & 0.793 & $0.236^{* *}$ & $0.311^{* *}$ & 0.793 \\
\hline & & CR & 0.79 & 0.73 & 0.83 \\
\hline & & AVE & 0.59 & 0.56 & 0.63 \\
\hline & $\begin{array}{l}=3.18, C \\
* * * * \text { mode }\end{array}$ & $\begin{array}{l}\text { GFI }= \\
\text { es for }\end{array}$ & $\begin{array}{l}\mathrm{I}=0.928 \\
\text { tory facto }\end{array}$ & $\begin{array}{l}\text { MSEA = } \\
\text { sis (CFA) }\end{array}$ & \\
\hline
\end{tabular}

Notes: CSR, corporate social responsibility; PRB, proenvironmental behavior; EPF, environmental performance The values in bold represent square root value of AVE for each variable; ${ }^{* *}$ value is significant.

Finally, in Table 3, we also presented the results of convergent validity, which can be observed through the AVE values for each variable; if the value of AVE is more than 0.5, then the criteria of convergent validity is established.

In order to test the hypotheses of the present study, we used a structural equation modeling (SEM) technique in AMOS using the maximum likelihood method, which is a covariance-based SEM approach. In doing so, we ran the structural model twice; the first time, we only tested the direct results without any interventions of a mediator. The results of our direct model produced significant outputs, as shown in Table 4 
$\left(\mathrm{H} 1 ; \beta=0.211^{* *}\right.$, S.E $=0.034, \mathrm{LLCI}=0.239, \mathrm{ULCI}=0.559, p<0.05$ and H2; $\beta=0.238^{* *}$, $\mathrm{LLCI}=0.196$, ULCI $=0.368, p<0.05)$, establishing that our Hypotheses 1 and 2 are accepted. Thus, it was statistically proven that $\mathrm{H} 1$ and $\mathrm{H} 2$ are accepted. Further, the results of direct model analysis confirmed that CSR positively predicts employee proenvironmental behavior and environmental performance, but the impact of CSR on environmental performance is more influential on environmental performance as compared to employee proenvironmental behavior, as per the results of the direct effect model (the upper span of Table 4). Finally, we ran the structural model again with the inclusion of employee proenvironmental behavior as a mediator. For this purpose, we used the bootstrapping option in AMOS by using a large bootstrap sample of 2000. The results are reported in the lower span of Table 4, which prove that environmental behavior mediates between micro-CSR and environmental performance (the beta was reduced from 0.238 to 0.116 but remained significant). As per the guidelines of Baron and Kenny [50], if the beta value between the direct relationship of the independent variable and dependent variable is reduced after the inclusion of a mediator in the model, but remains significant, it means there is a partial mediation effect between the relationship of independent variable and dependent variable through the mediator. So, employees' proenvironmental behavior is a partial mediator between CSR and environmental performance. Hence, we establish that micro-CSR activities directly and indirectly, via environmental behavior, influence the environmental performance of an organization. These results establish that $\mathrm{H} 3$ is true and accepted $\left(\mathrm{H} 3 ; \beta=0.116^{* *}\right.$, S.E $\left.=0.0192, \mathrm{LLCI}=0.098, \mathrm{ULCI}=0.136, p<0.05\right)$. Thus, H3 of the present study is accepted. Hence, all three hypotheses (H1, H2 and H3) of the present study are accepted in the light of the empirical results.

Table 4. Hypothesis testing.

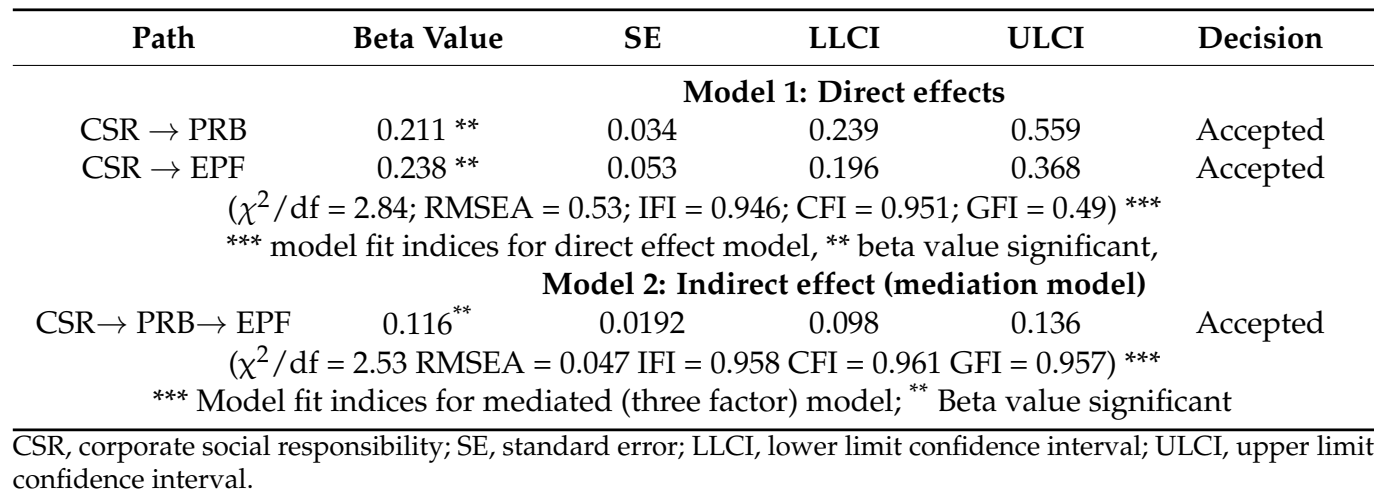

\section{Discussion}

Over the last two decades, the topic of CSR has become increasingly interesting to researchers and experts. However, most of these studies have addressed CSR activities at the institutional level. Reasonably, scholars have called for more research on the basics of micro-CSR; in particular, CSR at the individual level. In addition, Hameed et al. [51] noted that employees' perceptions of their employer's CSR practices may have a more direct and effective influence on those employees' reactions who have a consideration for the environment The objective of this article was to examine the impact of micro-CSR activities on organizational environmental performance with the mediating effect of employees' proenvironmental behavior in accordance with the environment. To achieve this and to respond to the lack of existing research in the area, the current study tested the proposed model in the banking sector of Pakistan and revealed that micro-CSR is positively related with the environmental performance of a bank and that employee proenvironmental behavior mediates this relationship.

Notwithstanding the link between CSR and environmental performance, the existing literature does not have sufficient evidence, and especially in the context of developing countries, the literature is scant. Our results have contributed to the available literature 
by showing that employees perceiving their organization to be actively involved in CSR activities pertinent to environment has a positive impact on their environmental behavior. Therefore, organizations implementing socially responsible policies create an environment that is adapted to the relevant values and personal level and consequently creates proenvironmental behaviors; these findings are also in line with previous studies [39,52-54]. Firms can use CSR initiatives to increase environmental performance, as CSR places emphasis on social and environmental issues. However, the relationship between CSR and environmental performance has not been studied in detail. Hence, this study examines the relationship between CSR and environmental performance.

When employees of an organization see that their organization is showing a serious concern towards preserving nature, it urges them to promote this motive of the organization on their part too; hence, employees are self-motivated to show proenvironmental behavior for a sustainable future. Further, the results of the present study also revealed that the microlevel CSR activities of an organization are important touchpoints to shape the view of self and nature in the context of employees' workplace behavior. Because the CSR activities of an organization moralize the employees to rethink their view towards self and nature, they are motivated to actuate such actions at the individual level, through which they can contribute to reducing the level of environmental dilapidation. Hence, sustainability may be regarded as a "new normal" to change the behavior of oneself towards nature. Wellplanned CSR activities play a significant role in improving the environmental consciousness of employees. Improving environmental performance remains an important issue for many organizations due to sustainability pressures from consumers and communities. Our results further establish that the employees of an organization are key players in improving environmental sustainability through their prosocial behavior. Hence, if the employees at each level, irrelevant to a specific industry, are dedicated to preserving the environment, then it follows that the widespread issue of environmental degradation can be encountered in a meaningful way.

Although much attention has been paid to the adoption of new technologies, product development and product performance, awareness of the role of each employee in reducing the environmental footprint of the organization is growing. We are not the first to propose that employees are imperative in preserving the environment and that their proenvironmental behavior is shaped by microlevel CSR activities of an organization; indeed, numerous scholars in the recent literature have reported the same findings [55-58].

\subsection{Implications}

The results of the present study have some important implications for theory and practice; to begin with, the findings of our study enrich the extant literature of CSR in the context of microfoundations to improve environmental performance, as the majority of prior studies have addressed this issue through establishing CSR and environment management relationship at the macrolevel. Likewise, the study at hand also adds to the existing literature in the context of a developing country such as Pakistan, where the issue of climate change is very serious and calls for emergency measures at each level. Lastly, the theoretical importance of the present study is significant as it adds to existing literature by introducing employee proenvironmental behavior as a mediator between the relationship of microlevel CSR and environmental performance.

Our results provide interesting implications for practice as well. Preliminary results of the present study suggest an important role of CSR in improving environmental performance. In particular, employees' perceptions of the organization's socially responsible image have a significant impact on employees' active involvement in environmental protection activities. Therefore, if organizations want to promote environmental ethics at the individual level, they can benefit from the use of CSR activities. However, given that the current results focused on employee perspectives, it is important to keep in mind that organizations need to liaise with their employees to make them realize that the organization is effectively involved in environmental protection activities. Hence, in this way, 
organizations can improve the view of their employees toward the environment. Unfortunately, in Pakistan, such an orientation towards the environment is essentially non-existent, which is alarming for a country that is already facing extreme climate change conditions. It is very important for policymakers to use the interventions of the present study to involve the workforce in improving environment sustainability for a better and sustainable future. Policymakers can strengthen the CSR plans by addressing environmental responsibility at a higher level. To address this, the implementation and monitoring of the principle of CSR disclosure can be further strengthened.

Although CSR spending of organizations have increased over the years and there are significant efforts made by developed nations to invest CSR funds into environmental activities, the matter is different for developing nations, as they are spending CSR funds on social activities, as concern for the environment is not their prime objective. This is a serious concern for developing nations regarding environmental management. Our research suggests that the firms should be encouraged to invest in improving the environment as part of their social responsibility. One possible solution to change the current scenario may be suitable interventions (in terms of clear policymaking) from the government of Pakistan in order to make businesses realize that climate change is a burning issue at present and that organizations should take every possible step to reduce environmental hazards resulting from their business activities.

In addition, there should be platforms that raise awareness of various environmental issues and ways to help reduce environmental degradation. Corporate executives can use the findings of the present study as a benchmark to evaluate their CSR strategies. Firms can invest in and improve the environment in the framework of CSR. Moreover, they can make an effort to include environmental reporting in their annual reports, business liability reports and/or CSR reports.

\subsection{Recommendations}

Training and education should focus on the formation of knowledge about the environment, not on changing the attitude of employees to the environment. In addition, it may be more effective to focus on both the group and individual level. While training may involve additional cost, it will generate better results in long run that will offset this additional cost. Similarly, monetary and nonmonetary rewards for the organization should be inclusive and focused on environmental issues, which will motivate more employees than the already encouraged minority. Environmental responsibility should be integrated into core management philosophy so that employees understand that it is important for their organization and management. The biggest sustainability task that managers should be responsible for is taking into account the environmental concerns at the group level and at the individual level. This information should not be the result of the organizational level as a whole, but should be directed to each group, and if possible, to individuals. Personal focus may be on key roles such as managers, team leaders and staff as well as key operations.

\section{Conclusions}

To conclude, there is no way for modern businesses to negate the importance of sustainability because it has been emerging as an important concern for everyone. Especially in the context of developing nations, this issue is of utmost importance as most developing nations are facing extreme climate change conditions due to their poor environmental management strategies. Pakistan, being a developing nation, is without exclusion to this challenge of climate change, as the country has been a victim of extreme climatic conditions during the last two decades and it is expected that if serious measures are not taken, then this situation of extreme climatic conditions will prevail in the future too. In this connection, the country can help itself from the experience of the West, such as the EU and other developed countries where some extraordinary efforts have been taken at every level to preserve nature. Further, the management of organizations is encouraged 
to work with employees in relation to personal and environmental factors to reduce the pace of environmental degradation in the country. Due to the growing concern for social responsibility, especially the responsibility for the environment, it is important to realize the human impact on the company's environmental performance. Because people spend a significant amount of their time at work, it is important for them to understand that their behavior can significantly contribute towards the company's impact on the environment. It is clear to us that the potential for successful environmental change arises when organizations integrate sustainability or CSR processes into key business functions, such as human resource management and organizational management. In a nutshell, this is the time to purposefully address the issue of environmental sustainability by engaging the employees of an organization proactively, because this is one of the viable strategies through which a better and sustainable future can be achieved.

\section{Limitations and Future Research Directions}

The current research needs to address some limitations. First, although the use of time-lagged data decreases the probability of common method bias, it does not prevent some of the causal extrapolations, so in order to improve the causality, future researchers should use longitudinal data. Second, the data used in the present study was collected from Pakistan, a country where the concept of CSR is still at an introductory stage, and especially the effect of CSR to mitigate the impact of climate change, so generalizing the results to other countries may be risky as the phenomenon of CSR is perceived differently in different cultures; future research conducted in other developing nations may improve our understanding of this relationship. Lastly, additional mediators may be introduced; for instance, an ethical climate can influence employee attitudes (e.g., accountability, ethical outcomes and commitments) towards proenvironmental behavior. Therefore, future research should address these constructs as potential mediators in the relationship between CSR and environmental performance.

Author Contributions: L.K., M.S.S., N.A., M.S., Z.L., M.Z.-U.-D., D.B. contributed to conceptualization, formal analysis, investigation, methodology and writing and editing the original draft. All authors have read and agreed to the published version of the manuscript.

Funding: This research received no external funding.

Informed Consent Statement: Informed consent was obtained from the respondents of the survey.

Data Availability Statement: The data will be made available upon request to the corresponding author.

Conflicts of Interest: The authors declare no conflict of interest.

\section{References}

1. Yin, J. Institutional drivers for corporate social responsibility in an emerging economy: A mixed-method study of Chinese business executives. Bus. Soc. 2017, 56, 672-704. [CrossRef]

2. Yuan, Y.; Lu, L.Y.; Tian, G.; Yu, Y. Business strategy and corporate social responsibility. J. Bus. Ethics 2020, 162, 359-377. [CrossRef]

3. Barauskaite, G.; Streimikiene, D. Corporate social responsibility and financial performance of companies: The puzzle of concepts, definitions and assessment methods. Corp. Soc. Responsib. Environ. Manag. 2020, 28, 278-287. [CrossRef]

4. Ruggiero, P.; Cupertino, S. CSR strategic approach, financial resources and corporate social performance: The mediating effect of innovation. Sustainability 2018, 10, 3611. [CrossRef]

5. Chao, A.C.; Hong, L. Corporate social responsibility strategy, environment and energy policy. Struct. Chang. Econ. Dyn. 2019, 51,311-317. [CrossRef]

6. Fernando, Y.; Jabbour, C.J.C.; Wah, W.-X. Pursuing green growth in technology firms through the connections between environmental innovation and sustainable business performance: Does service capability matter? Resour. Conserv. Recycl. 2019, 141, 8-20. [CrossRef]

7. Roberts, A.D. Corporate social responsibility (CSR): Governments, institutions, businesses, and the public within a smart city context. Handb. Smart Cities 2020, 1-25.

8. Du, Y.; Wang, X.; Zhang, L.; Feger, K.-H.; Popp, J.; Sharpley, A. Multi-stakeholders' preference for best management practices based on environmental awareness. J. Clean. Prod. 2019, 236, 117682. [CrossRef] 
9. Pata, U.K. Renewable and non-renewable energy consumption, economic complexity, $\mathrm{CO}_{2}$ emissions, and ecological footprint in the USA: Testing the EKC hypothesis with a structural break. Environ. Sci. Pollut. Res. 2020, 28, 1-16. [CrossRef]

10. Solarin, S.A.; Al-Mulali, U.; Gan, G.G.G.; Shahbaz, M. The impact of biomass energy consumption on pollution: Evidence from 80 developed and developing countries. Environ. Sci. Pollut. Res. 2018, 25, 22641-22657. [CrossRef]

11. Fahad, S.; Wang, J. Climate change, vulnerability, and its impacts in rural Pakistan: A review. Environ. Sci. Pollut. Res. 2020, 27, 1334-1338. [CrossRef] [PubMed]

12. Kraus, S.; Rehman, S.U.; García, F.J.S. Corporate social responsibility and environmental performance: The mediating role of environmental strategy and green innovation. Technol. Forecast. Soc. Chang. 2020, 160, 120262. [CrossRef]

13. Kucharska, W.; Kowalczyk, R. How to achieve sustainability?-Employee's point of view on company's culture and CSR practice. Corp. Soc. Responsib. Environ. Manag. 2019, 26, 453-467. [CrossRef]

14. Rupp, D.E.; Mallory, D.B. Corporate social responsibility: Psychological, person-centric, and progressing. Annu. Rev. Organ. Psychol. Organ. Behav. 2015, 2, 211-236. [CrossRef]

15. Brieger, S.A.; Anderer, S.; Fröhlich, A.; Bäro, A.; Meynhardt, T. Too much of a good thing? On the relationship between CSR and employee work addiction. J. Bus. Ethics 2020, 166, 311-329. [CrossRef]

16. Rehman, A.; Ullah, I.; Ullah, Z.; Zeeshan, M.; Hussain, A.; Rahman, H.U. Adoption of green banking practices and environmental performance in Pakistan: A demonstration of structural equation modelling. Environ. Dev. Sustain. 2021, 1-21. [CrossRef]

17. World Bank. Labor Force, Total-Pakistan. Available online: https://data.worldbank.org/indicator/SL.TLF.TOTL.IN?locations= PK (accessed on 21 November 2020).

18. Sun, H.; Rabbani, M.R.; Ahmad, N.; Sial, M.S.; Cheng, G.; Zia-Ud-Din, M.; Fu, Q. CSR, co-creation and green consumer loyalty: Are green banking initiatives important? A moderated mediation approach from an emerging economy. Sustainability 2020, 12, 10688. [CrossRef]

19. Szegedi, K.; Khan, Y.; Lentner, C. Corporate social responsibility and financial performance: Evidence from pakistani listed banks. Sustainability 2020, 12, 4080. [CrossRef]

20. Prasad, M.; Mishra, T.; Bapat, V. Corporate social responsibility and environmental sustainability: Evidence from India using energy intensity as an indicator of environmental sustainability. Iimb Manag. Rev. 2019, 31, 374-384. [CrossRef]

21. Tang, Z.; Tang, J. Stakeholder-firm power difference, stakeholders' CSR orientation, and SMEs' environmental performance in China. J. Bus. Ventur. 2012, 27, 436-455. [CrossRef]

22. Carroll, A.B. A three-dimensional conceptual model of corporate performance. Acad. Manag. Rev. 1979, 4, 497-505. [CrossRef]

23. Bowen, H.R.; Johnson, F.E. Social Responsibility of the Businessman; Harper: New York, NY, USA, 1953.

24. Nazari, J.A.; Hrazdil, K.; Mahmoudian, F. Assessing social and environmental performance through narrative complexity in CSR reports. J. Contemp. Account. Econ. 2017, 13, 166-178. [CrossRef]

25. Wang, H.; Tong, L.; Takeuchi, R.; George, G. Corporate Social Responsibility: An Overview and New Research Directions: Thematic Issue on Corporate Social Responsibility; Academy of Management Briarcliff Manor: New York, NY, USA, 2016.

26. Wang, Z.; Sarkis, J. Corporate social responsibility governance, outcomes, and financial performance. J. Clean. Prod. 2017, 162, 1607-1616. [CrossRef]

27. Shabbir, M.S.; Wisdom, O. The relationship between corporate social responsibility, environmental investments and financial performance: Evidence from manufacturing companies. Environ. Sci. Pollut. Res. 2020, 27, 1-12. [CrossRef]

28. Halme, M.; Rintamäki, J.; Knudsen, J.S.; Lankoski, L.; Kuisma, M. When is there a sustainability case for CSR? Pathways to environmental and social performance improvements. Bus. Soc. 2020, 59, 1181-1227. [CrossRef]

29. Anser, M.K.; Yousaf, Z.; Majid, A.; Yasir, M. Does corporate social responsibility commitment and participation predict environmental and social performance? Corp. Soc. Responsib. Environ. Manag. 2020, 27, 2578-2587. [CrossRef]

30. Aju, O.; Beddewela, E. Afrocentric attitudinal reciprocity and social expectations of employees: The role of employee-centred CSR in Africa. J. Bus. Ethics 2020, 161, 763-781. [CrossRef]

31. Afsar, B.; Al-Ghazali, B.M.; Rehman, Z.U.; Umrani, W.A. The moderating effects of employee corporate social responsibility motive attributions (substantive and symbolic) between corporate social responsibility perceptions and voluntary pro-environmental behavior. Corp. Soc. Responsib. Environ. Manag. 2020, 27, 769-785. [CrossRef]

32. Bouraoui, K.; Bensemmane, S.; Ohana, M.; Russo, M. Corporate social responsibility and employees' affective commitment. Manag. Decis. 2019, 57, 152-167. [CrossRef]

33. Farid, T.; Iqbal, S.; Ma, J.; Castro-González, S.; Khattak, A.; Khan, M.K. Employees' perceptions of CSR, work engagement, and organizational citizenship behavior: The mediating effects of organizational justice. Int. J. Environ. Res. Public Health 2019, 16, 1731. [CrossRef]

34. Ferri, G.; Pini, M. Environmental vs. social responsibility in the firm. Evidence from Italy. Sustainability 2019, 11, 4277. [CrossRef]

35. Brammer, S.; He, H.; Mellahi, K. Corporate social responsibility, employee organizational identification, and creative effort: The moderating impact of corporate ability. Group Organ. Manag. 2015, 40, 323-352. [CrossRef]

36. Homans, G.C. Social Behavior: Its Elementary Forms; Harcourt Brace Jovanovich: San Diego, CL, USA, 1974.

37. Gouldner, A.W. The norm of reciprocity: A preliminary statement. Am. Sociol. Rev. 1960, 25, 161-178. [CrossRef]

38. Goyal, S.; Routroy, S.; Singhal, A. Analyzing environment sustainability enablers using fuzzy DEMATEL for an Indian steel manufacturing company. J. Eng. Des. Technol. 2019, 17, 300-329. [CrossRef] 
39. Islam, T.; Ali, G.; Asad, H. Environmental CSR and pro-environmental behaviors to reduce environmental dilapidation. Manag. Res. Rev. 2019, 42, 332-351. [CrossRef]

40. Tanimoto, K. Do multi-stakeholder initiatives make for better CSR? Corp. Gov. Int. J. Bus. Soc. 2019, 19, 704-716. [CrossRef]

41. Tolppanen, S.; Kang, J. The effect of values on carbon footprint and attitudes towards pro-environmental behavior. J. Clean. Prod. 2020, 282, 124524. [CrossRef]

42. Koiwanit, J.; Filimonau, V. Carbon footprint assessment of home-stays in Thailand. Resour. Conserv. Recycl. 2021, 164, 105123. [CrossRef]

43. IQAir. Air Quality in Pakistan. Available online: https://www.iqair.com/us/pakistan (accessed on 3 January 2021).

44. Zou, Z.; Liu, Y.; Ahmad, N.; Sial, M.S.; Badulescu, A.; Zia-Ud-Din, M.; Badulescu, D. What Prompts Small and Medium Enterprises to Implement CSR? A Qualitative Insight from an Emerging Economy. Sustainability 2021, 13, 952. [CrossRef]

45. KPMG. Banking Results 2019. Available online: https:/ / assets.kpmg/ (accessed on 6 November 2020).

46. Turker, D. Measuring corporate social responsibility: A scale development study. J. Bus. Ethics 2009, 85, 411-427. [CrossRef]

47. Bissing-Olson, M.J.; Iyer, A.; Fielding, K.S.; Zacher, H. Relationships between daily affect and pro-environmental behavior at work: The moderating role of pro-environmental attitude. J. Organ. Behav. 2013, 34, 156-175. [CrossRef]

48. Blok, V.; Wesselink, R.; Studynka, O.; Kemp, R. Encouraging sustainability in the workplace: A survey on the pro-environmental behaviour of university employees. J. Clean. Prod. 2015, 106, 55-67. [CrossRef]

49. Harman, H.H. Modern Factor Analysis; University of Chicago press: Chicago, IL, USA, 1976.

50. Baron, R.M.; Kenny, D.A. The moderator-mediator variable distinction in social psychological research: Conceptual, strategic, and statistical considerations. J. Personal. Soc. Psychol. 1986, 51, 1173. [CrossRef]

51. Hameed, Z.; Khan, I.U.; Islam, T.; Sheikh, Z.; Khan, S.U. Corporate social responsibility and employee pro-environmental behaviors. South Asian J. Bus. Stud. 2019, 8, 246-265. [CrossRef]

52. Suganthi, L. Examining the relationship between corporate social responsibility, performance, employees' pro-environmental behavior at work with green practices as mediator. J. Clean. Prod. 2019, 232, 739-750. [CrossRef]

53. Tian, Q.; Robertson, J.L. How and when does perceived CSR affect employees' engagement in voluntary pro-environmental behavior? J. Bus. Ethics 2019, 155, 399-412. [CrossRef]

54. Popa, D.N.; Belenesi, M.; Rus, L. The correlation between the intellectual capital disclosure level and the stakeholder structure. Ann. Univ. Oradeaeconomic Sci. Ser. 2016, 25, 444-453.

55. Ahmed, M.; Zehou, S.; Raza, S.A.; Qureshi, M.A.; Yousufi, S.Q. Impact of CSR and environmental triggers on employee green behavior: The mediating effect of employee well-being. Corp. Soc. Responsib. Environ. Manag. 2020, 27, 2225-2239. [CrossRef]

56. Gligor-Cimpoieru, D.C.; Munteanu, V.P.; Nitu-Antonie, R.D.; Schneider, A.; Preda, G. Perceptions of future employees toward CSR environmental practices in tourism. Sustainability 2017, 9, 1631. [CrossRef]

57. Badulescu, D.; Bungau, C.; Badulescu, A. Sustainable development through sustainable businesses. An empirical research among master students. J. Environ. Prot. Ecol. 2015, 16, 1101-1108.

58. Shahzad, M.; Qu, Y.; Javed, S.A.; Zafar, A.U.; Rehman, S.U. Relation of environment sustainability to CSR and green innovation: A case of Pakistani manufacturing industry. J. Clean. Prod. 2020, 253, 119938. [CrossRef] 